\title{
The Use of Adapted Games for Assessment of Mathematics and Monetary Skills
}

\author{
Gabriele Gris ${ }^{\mathbf{1}}$ \\ Universidade Federal de São Carlos, São Carlos, SP, Brasil \\ Hans Werner Alves \\ Universidade Estadual de Londrina, Londrina, PR, Brasil \\ Grauben José Alves Assis \\ Universidade Federal do Pará, Belém, PA, Brasil \\ Silvia Regina de Souza \\ Universidade Estadual de Londrina, Londrina, PR, Brasil
}

\begin{abstract}
This study aims to evaluate the effects of adapted games over preschool child performance in arithmetic and monetary abilities. The subjects were eight children of Childhood Education, distributed in two Experimental Groups. For both groups, using adapted dominos, the following relations were taught and tested: printed numerals (A), dot sets (B), addition operations (C), printed values (D), pictures of banknotes/coins (E). First, relations $\mathrm{AB} / \mathrm{BA}$ and $\mathrm{AC} / \mathrm{CA}$ were taught, testing $\mathrm{BC} / \mathrm{CB}$ relation. Later, relation $\mathrm{DC} / \mathrm{CD}$ was taught and relations $\mathrm{AD} / \mathrm{DA}$ and $\mathrm{DB} / \mathrm{BD}$ were tested. Finally, relation $\mathrm{DE} / \mathrm{ED}$ was taught and relations $\mathrm{EB} / \mathrm{BE}, \mathrm{EC} / \mathrm{CE}$ and $\mathrm{AE} / \mathrm{EA}$ were tested. Evaluations of stimulus naming were conducted in Pretest, Probe and Posttest stages. For Group one, the evaluations of stimuli naming were conducted via card display, and for Group two were used adapted games. Evaluation results suggest that the use of adapted games may contribute to lower tests variability in stimuli naming.
\end{abstract}

Keywords: Games, arithmetic (mathematic), money handling, relationship network, domino.

\section{Utilização de Jogos Adaptados para Avaliação de Habilidades Matemáticas e Monetárias}

\section{Resumo}

Este estudo teve por objetivo avaliar os efeitos de jogos adaptados sobre a avaliação do desempenho de pré-escolares no aprendizado de habilidades matemáticas e monetárias. Participaram oito crianças da Educação Infantil, distribuídas em dois Grupos Experimentais. Para ambos os grupos, por meio de dominós adaptados, foram ensinadas e testadas relações entre numerais impressos (A), conjuntos de pontos (B), operações de adição (C), valores impressos (D) e figuras de cédulas e moedas (E). Inicialmente foram ensinadas as relações $\mathrm{AB} / \mathrm{BA}$ e $\mathrm{AC} / \mathrm{CA}$ e testadas as relações $\mathrm{BC} / \mathrm{CB}$. Posteriormente foram ensinadas as relações $\mathrm{DC} / \mathrm{CD}$, testadas as relações $\mathrm{AD} / \mathrm{DA}$ e $\mathrm{DB} / \mathrm{BD}$. Finalmente ensinou-se a relação DE/ED, testando-se em seguida as relações EB/BE, EC/CE e AE/EA. Avaliações de nomeação

Mailing address: Alameda das Papoulas, 90, Apto 14, São Carlos, SP, Brasil, 13566-545. Fone: (43)996800188. E-mail: grisgabriele@gmail.com

Financing: Fundação Araucária and Programa de Iniciação Científica of Universidade Estadual de Londrina (IC/UEL).

The authors thank Fundo de Apoio ao Ensino, à Pesquisa e à Extensão/Universidade Estadual de Londrina (FAEPE/UEL) - PUBLIC 2016 for financing the paper's translation. 
dos estímulos e de resolução de operações de adição foram realizadas em Pré-teste, Sondas e em Pósteste. Para o Grupo 1 as avaliações de nomeação de estímulos foram conduzidas por meio da apresentação de cartões e para o Grupo 2 foram utilizados jogos adaptados. Observou-se, para ambos os grupos, melhores resultados na resolução de operações de adição. Os resultados das avaliações sugerem que o uso de jogos adaptados pode contribuir para menor variabilidade nas avaliações de nomeação de estímulos.

Palavras-chave: Jogos, matemática, manuseio de dinheiro, rede de relações, dominó.

\section{Utilización de Juegos Adaptados para Evaluación de Habilidades Matemáticas y Monetarias}

\section{Resumen}

Este estudio tuvo como objetivo investigar los efectos del uso de juegos de dominó adaptados sobre la evaluación del desempeño de preescolares en el aprendizaje de habilidades matemáticas y monetarias. Participaron ocho niños de la Educación Infantil, distribuidos en dos Grupos Experimentales. Para ambos los grupos, por medio de dominó adaptados, fueron enseñadas y testadas relaciones entre numeral impreso (A), conjunto de puntos (B), operación de suma (C), valor impreso (D) y imágenes de billetes y monedas. Inicialmente fueran enseñadas las relaciones $\mathrm{AB} / \mathrm{BA}$ y $\mathrm{AC} / \mathrm{CA}$, testándose las relaciones $\mathrm{BC} / \mathrm{CB}$. Posteriormente fueran enseñadas las relaciones $\mathrm{DC} / \mathrm{CD}$, testándose las relaciones $\mathrm{AD} / \mathrm{DA}$ y $\mathrm{DB} / \mathrm{BD}$. Finalmente fueran enseñadas las relaciones $\mathrm{DE} / \mathrm{ED}$, testándose las relaciones $\mathrm{EB} / \mathrm{BE}, \mathrm{EC} / \mathrm{CE}$ y AE/EA. Evaluaciones de nombramiento de estímulos y de resolución de operaciones de suma fueron realizadas en prueba previa, sondeos y en post-prueba. Para el Grupo 1 las evaluaciones de nombramiento de estímulos fueron conducidas por medio de la presentación de tarjetas y para el Grupo 2 fueron utilizados juegos adaptados. Se observó, para ambos los grupos, mejores resultados en la resolución de operación de suma. Los resultados de las evaluaciones sugieren que el uso de juegos adaptados puede contribuir para resultados con menor variabilidad en las evaluaciones de nombramiento.

Palabras-clave: Juegos, matemática, manoseo de dinero, red de relaciones, dominó.

For some behavior analysts, the mathematical behavior can be understood as a network of relations between stimuli (environmental events) as well as signs of operations, algarisms, pictorial representations of large numbers and the responses issued by individuals on the basis of these relations. This definition brings the understanding of mathematical behavior of the explaination of the symbolic behavior based in the models of networks of relations and equivalence of stimuli offered and documented by Sidman and collaborators (Sidman, 1971; Sidman, Kirk, \& Willson-Morris, 1985; Sidman \& Tailby, 1982) among others. Teaching procedures and evaluation based on these models can be useful when teaching Mathematics.

The teaching of mathematics and monetary relations through the models of network of re- lations and the equivalence of stimuli has been done with different populations, such as children with typical development (Henklain \& Carmo, 2013; Monteiro \& Medeiros, 2002; Ribeiro, Assisi, \& Enumo, 2007), individuals with hearing disabilities (Magalhães \& Assis, 2011; Magalhães, Rossit, \& Assis, 2013), people with intellectual disabilities (Escobal, Rossit, \& Goyos, 2010; Hammond, Hirt, \& Hall, 2012; Stoddard, Brown, Hurlbert, Manoli, \& McIlvane, 1989), university students (Fields et al., 2009, the elderly (Rossit, Ramos, \& Lopes, 2010) and elderly people with memory loss (Cavaletti \& Carmo, 2012). The data obtained through these studies confirmed the economy and efficiency at the teaching process.

Most of these studies made use primarily of cards (Cavaletti \& Carmo, 2012; Haydu, Costa, 
$\&$ Pullin, 2006) and softwares (Prado \& de Rose, 1999; Rossit \& Goyos, 2009). Even where such procedures have been shown to be quite effective, according to Skinner (1968/1972), more effectively teaching is one whose arrangement of contingencies allows the largest quantity of possible reinforcers. Thus, it seems important to highlight that the literature of the area has shown the possibility of using games for the teaching of mathematics and of monetary relations. The educational games promote contact with natural consequences such as the interaction between the players and the learning of the proposed objectives, as well as arbitrary programmed consequences, how to earn points, achieve the highest score, beat the opponent (Panosso, Souza, \& Haydu 2015).

The game DimDim: Negociando \& Brincando! For example, was used to teach cash handling to five preschool children with five years of age in a study conducted by Xander, Haydu and Souza (2016). The study was divided into three steps: Pre-test, intervention and surveys. In steps of testing (pre-test and surveys) the skills of identification of bills and coins and the relationships between the value dictated and bills/coins, value printed and bills/coins and composition of values (CRMTS of addition) and operations of addition and subtraction. The step of intervention was performed by means of sessions of the game conducted by the researcher individually with each participant.

In the intervention sessions, initially the pawns were placed in the "beginning" and the players received five bills of $\mathrm{R} \$ 20.00$; five bills of R\$ $10.00 ; 10$ bills of R\$ 5.00; 10 bills of R\$ $2.00 ; 10$ coins of $\mathrm{R} \$ 1.00 ; 10$ coins of $\mathrm{R} \$ 0.50$ and 10 coins of $\mathrm{R} \$ 0.25$ each. The numbers obtained in the rolling of the dice indicate the number of spaces that the pawns should be moved on the board. In each space in which the pawn was positioned, the researcher read the card corresponding to the type of space and, if necessary, helped the participant to perform the task according to levels of aid pre-established. In addition to the results indicating that the game can be a tool for teaching the skills of cash handling, informal observations of the verbalizations of the participants pointed out that the game promotes an increase in the interest and confirms the acceptance in relation to technological resource.

Another study that employed games for the teaching of mathematical and monetary skills was developed by Godoy, Alves, Xander, Carmo and Souza (2015). This study aimed to investigate the effectiveness of games of dominoes adapted for the teaching of monetary relations to pre-school children. Two children from Elementary school participated of the research. The study was divided into three steps. In step 1, we evaluated the skills of appointment of numeral printed, printed value, value of bills/coins, sets and cash handling and operations of addition. In Step 2, it was taught the relationship between printed numeral and sets represented by dots $(\mathrm{AB} / \mathrm{BA})$ and between the printed numeral and operations of addition (AC/CA); it was tested the relationship between sets of points and operations of addition (BC/CC). In Step 3, it was taught the relationships between printed numeral and value printed $(\mathrm{AD} / \mathrm{DA})$ and value printed and figure of bills/coins (DE/ED) and tested the relations between value printed and set of points (DB/DB), figures of bills/coins and set of points (EB/BE), figures of bills and coin and addition operation (CE/EC) and value printed and operations of addition (DC/CD). Surveys were performed after the steps 2 and 3 .

The results showed that the games of dominoes were effective for the teaching of relations taught and tested. It was observed an increase in the percentages of correct answers in the resolution of operations of addition to both participants (from $0 \%$ in the pre-test to $80 \%$ at post-test). At the activities of cash handling, however, the percentages of correct responses were low. The authors suggested amendments that can contribute with better performance of participants in future studies. These they are: (a) removal of the symbol "?" after the equal sign of operations of addition, since this symbol is not a number, (b) reformulation in instruction for the resolution of operations of addition on the sheet of paper (c) collect data with more participants to produce more consistent results and (d) use games in steps of pre-test and surveys looking for a moti- 
vational variable that increases the interest in the job and improves the results in the tests.

From the suggestions made by Godoy et al. (2015), and considering the importance of organizing the contingencies of teaching so that they allow to obtain more reinforcers, the objective of this study was to investigate the effect of the use of games in the steps of pre-test and surveys to assess the performance of pre-school children in learning mathematical and monetary skills. To do so, there was a group whose assessments were conducted through the presentation of cards (Group 1) and a group whose evaluations were performed by means of adapted games (Group 2).

\section{Method}

\section{Participants and the Experimental Environment}

Eight children aged between 5 and 6 years participated, who attended Elementary school in a public teaching institution Children who could not resolve correctly mathematical operations of addition and the handling of money were selected, according to the assessment of pre-test. In order to implement their participation, parents signed an Informed Consent Form. The study was approved by the Ethics Committee with Human beings (Legal Opinion N\# 155/10). The sessions were conducted in a room provided by the institution, with table and chairs and the collection was performed without the interference of third parties.

\section{Equipment and Materials}

For the assessment of abilities cards with numerals printed, sets represented by dots, printed values and bills and coins were used, 12 color figures representing goods, money and a sheet with 26 operations to print (numerals interleaved with plus sign, for example $1+0=)$. In addition, for the evaluation of skills from group 2 it was used two sticks of the game Tapa Certo ${ }^{\circledR}$. It was used for the teaching of conditional relations 10 games of dominoes adapted and for recording and analysis of data it was used a camera cam- corder, tripod, the record sheet, pencil, pen and a notebook (Acer Aspire E1-571-6454).

\section{Experimental Stimuli}

It was used printed numerals from 1 to 5 (Class A); sets represented by black dots with numbers from 1 to 5 (Class B); operations of addition with algarisms 0 to 5 , with results of at the most 5 (Class C); values printed (Class D), represented as " $\mathrm{R} \$ 1.00 "$, " $\mathrm{R} \$ 2.00 "$, " $\mathrm{R} \$ 3.00 "$, "R $\$ 4.00 ", " R \$ 5.00 "$; figures of bills of $R \$ 2.00$ and bills $\mathrm{R} \$ 5.00$ and coins of $\mathrm{R} \$ 1.00$ (class $\mathrm{E}$ ) in which the sum of the value of the coins/bills/ bills-and-coins was no more than five reais.

Domino game adapted Each game was composed by 21 pieces adapted for teaching and the test of the following mathematical relations and monetary relationships and monetary relations: Domino 1 - teaching of relations between numeral printed and set of points $(\mathrm{AB} /$ $\mathrm{BA})$; Domino 2 - teaching of relations between the printed numeral and addition operation (AC/ $\mathrm{CA}$ ); Domino 3 - Test of relations between all the points and addition operation (BC/CC); Domino 4 - teaching of relations between value printed and addition operation (DC/CD); Domino 5 test of the relations between the printed numeral and value printed (AD/DA); Domino 6 - Test of relations between value printed and set of points (DB/DB); Domino 7 - teaching of relations between value printed and figures of bills and coin (DE/ED); Domino 8 - Test of relations between figures of bills and coin and set of points (EB/ $\mathrm{BE}$ ); Domino 9 - test of relations between figures of bills and coin and operations of addition (CE/ EC); Domino 10 - test of the relations between the printed numeral and figures of bills and coin (AE/EA).

The parts of the domino games were made with wood, with dimensions of $6,0 \mathrm{~cm} \times 3,0 \mathrm{~cm} \times$ $1.0 \mathrm{~cm}$. Figures, numbers and operations of addition printed in blank sheet were duly glued on each piece. Each piece of domino presented both sides with printed stimuli and none of the pieces presented both sides with stimuli of the same class. Figure 1 illustrates the faces of dominoes used in the study and the arrangement of the pieces during the matches. 


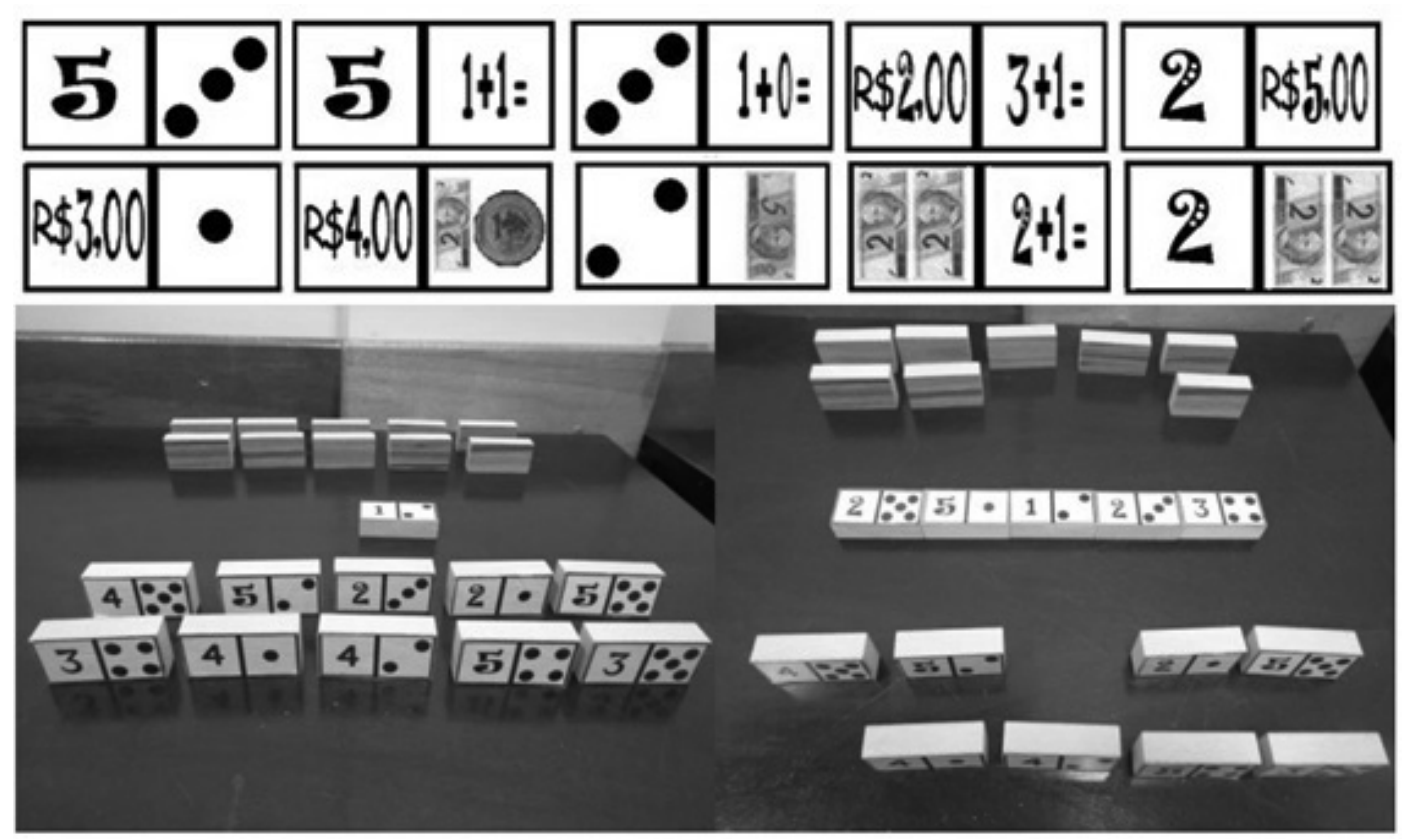

Figure1. Models of parts used in games (dominoes 1 to 5 at the first line and 6 to 10 at the second) and arrangement of the pieces of domino on the table during the matches.

\section{Procedure}

The study was divided into two steps. (a) skills assessment (Pre-test, surveys and post-test) that were conducted differently between the two experimental groups and (b) intervention (teaching and test of conditional relations), conducted equally among the groups. In both steps, the participants' responses were recorded by a second experimenter and the sessions were filmed.

\section{Skills Assessment}

\section{Group 1.}

Appointment of numeral printed. Five cards with the numbers printed were presented only once and in a random manner to the participants with the following statement: "-This is a number. Do you know what number this is? If you do not know, you do not need to respond, just say that you do not know."

Appointment of the number of elements in the set. It was presented at random five cards with sets represented by black dots to the participants together with the following statement: -can you tell me how many 'little balls' there are here? If you do not know, you do not need to respond, just say that you do not know."
Appointment of value printed. The five cards with the values printed were presented at random to the participant along with the following statement: "-Do you know what the price written on this card is? If you do not know, you do not need to respond, just say that you do not know." Only full responses were considered correct, for example, "1 Real" and not just "one".

Appointment of the value of bills and coins. The coin of 1 real and the 2 and 5 reais were presented separately and in a random order to participants with the following statement: "-Do you know how much money there is here? If you do not know, you do not need to respond, just say that you do not know." Only the correct answers were considered correct.

Resolution of operations of addition. A sheet with 26 operations of addition and a colorful pen were delivered to the participant with the following statement: "-In this sheet there are some calculation that need to be resolved. If you know how to resolve them, you can do it. If you do not know, you can give me back the sheet".

Cash handling. It was held in the form of a purchase of goods. On the table 12 cards that represented the goods to be purchased were distributed (toys, fruits, sweets etc.), and bills of 2 
and 5 reais and fictional coins of 1 real. Then, the following instruction was given: "- I have here several bills and coins and would like to play with you. Imagine that you are in the market. "What would you like to buy first?" As soon as the participant chose a product, the researcher would inform the price (from 1 to 5 dollars) and would give instructions on how the participant should pay it, using only bills, only coins or bills and coins. No feedback was provided, regardless of the value delivered by the participant.

\section{Group 2.}

Appointment of numeral printed and figures of bills and coin. Figures of 2, 5, 10 and 20 reais, coins of 25 cents and 1 Real, numbers from 0 to 9 and Figures with stimuli that were not taught by means of games (for example, cake, dog etc.) were arranged on the table. Then, cards similar to those shown on the table were distributed to the participant and to the researcher. The participant received the cards on which were printed the bills 2 and 5 reais and the coin of 1 real and the cards with the numbers from 1 to 5 (one card of each), as well as two cards with figures not taught in dominoes. The researcher received the cards with bills of 10 and 20 reais and the coin of 25 cents printed beyond the cards with the numbers $0,6,7,8$ and 9 (a card with each number) and two figures. After the distribution of the cards, the participant should draw one and name it aloud, tapping on the card similar laid on the table with a stick used in the game "Tapa Certo ${ }^{\circledR}$ ". It was informed to the participant that if he did not know to name, he could just hit with the stick on the card. Then, the researcher raffled one of his cards, appointed it and hit with the stick on the card. The player who gathered all their cards first was the winner. In order to not to lead the game in extinction, they were followed by praise only the correct answers for the appointment of figures (cake, dog etc.). The other moves did not produce any consequences by the researcher.

Appointment of set and value printed. It was conducted in a similar way the test for the appointment of numeral printed and figures of bills and coin, but stimuli of classes value printed and set of points were used.
Resolution of operations of addition. Initially, a sheet containing four columns with operations of addition and four columns with their results scrambled, was delivered to the participant and the following statement was provided "- At this sheet there are some calculation that need to be resolved. Match with a line, the calculation with their results. You can use the fingers to count. For example, $0+0$ is equal to zero [making the example of the sheet]. If you do not know how to perform, you can return the sheet". This activity had 20 operations of addition with two portions, as they were presented in the dominoes. Then another sheet containing seven operations of addition with more than two portions, with the result in the form of multiple choice was delivered and the following instruction was given: "mark with an $\mathrm{X}$ the numeral corresponding to the result of each calculation [showing the example in the sheet]. If you do not know how to perform, you can return the sheet".

Cash handling. It was performed by means of the game of the market, similar in structure to one conducted for the Group 1.

\section{Intervention}

Figure 2 shows the relations that have been taught and tested throughout the study.

Teaching They were taught the relations AB/BA (Domino 1), AC/AC (Domino 2), DC/ CD (Domino 4) and/ED (Domino 7). Before starting the game, the researcher taught how the parts should be arranged with the model (for example "- the number one goes with a little ball, the number two goes with two little balls" etc.) and requested that the participant paired a part with another pointed out by the researcher. If the participant responded correctly, the same part was separate from the others and placed in the center of the table for the beginning of the game (carretão) and the others were scrambled and separated equally between the participant and the researcher. The participant always started the game by placing a piece beside the carretão.

The participants played with the same domino until he hit at least $80 \%$ of the moves. At this stage, adjustments were followed by compliments and errors by corrections made by the 


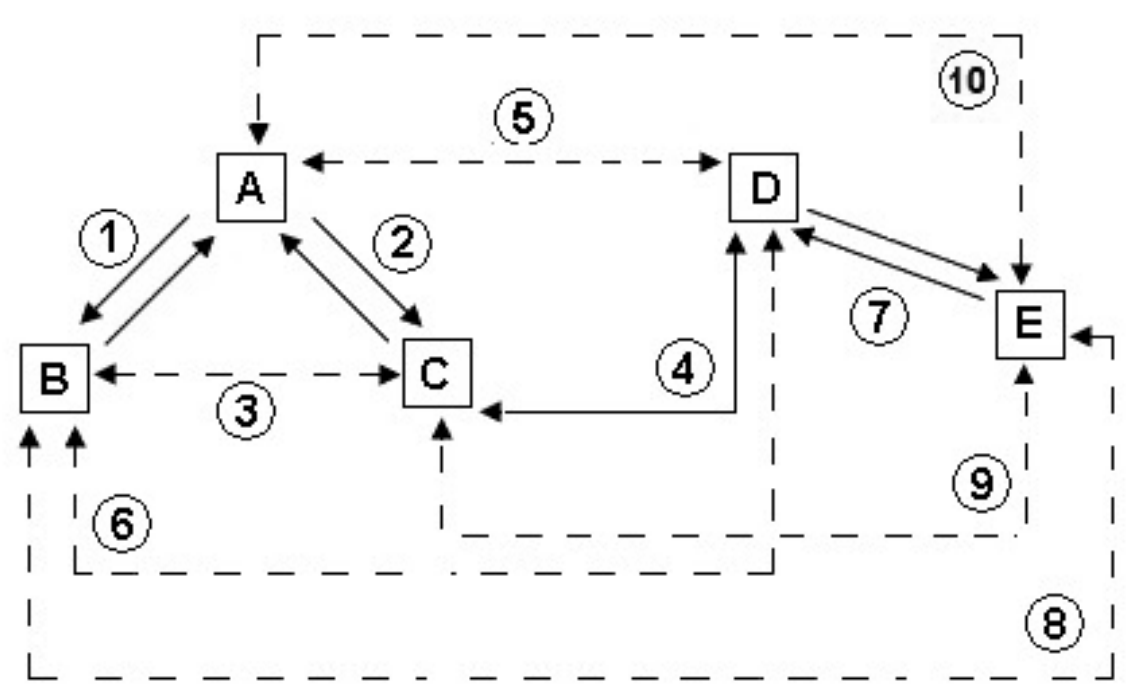

Figura 2. Relations taught and tested throughout the study. The letters represent the sets of stimuli in accordance with distinct topographies $(A=$ Numbers; $B=$ sets of points; $C=$ addition; $D=$ Values

Printed; and= figures bills and coins). The numbers indicate the order in which the practice sessions and tests were performed; the entire arrows represent the relations taught and dotted lines the relationships tested.

researcher who helped the participant to pair the part correctly, in accordance with the difficulties presented.

Test. In steps of testing it was found that the emergence of relations $\mathrm{BC} / \mathrm{CB}$ (Domino 3), AD/DA (Domino 5), DB/BD (Domino 6), EB/ BE (Domino 8), EC/EC (Domino 9) and AE/EA (Domino 10). With the exception of the relation $\mathrm{BC} / \mathrm{CB}$, if the participant did not reach the criterion of $80 \%$ of pairs in accordance with the expected by the researcher, the game went on to the next stage. For the relation $\mathrm{BC} / \mathrm{CB}$, if the criterion was not reached, the same game of domino was repeated at the next session. If even though the criterion was not reached, the phase of teaching (Domino 2) was carried out and a new test session conducted. If the criterion was still not reached, it was ended the child's participation in the study. During the test sessions it was not provided any consequence to the moves of the participant. This was previously informed to the participant by means of the following instruction: "- Today, you will play alone and I will not be able to help you".

\section{Results}

In relation to the participants in Group 1 it was needed 24 sessions so that the $\mathrm{P} 1$ concluded the study, 12 for the $\mathrm{P} 2$ and $\mathrm{P} 3$ and 11 sessions for the $\mathrm{P} 4$, totaling $4 \mathrm{~h}$ and $55 \mathrm{~min}, 54$ minutes, $1 \mathrm{~h}$ and $20 \mathrm{~min}$ and 43 minutes of teaching, respectively for P1, P2, P3 and P4. To the participants of the Group 2 it was used 11 sessions (teaching and test) for P5, P7 and P8, and 14 sessions for P6. The teaching time for the P5, P6, P7 and P8 were respectively 51 minutes $1 \mathrm{~h}$ and $40 \mathrm{~min}, 54$ minutes and 37 minutes. Figure 3 shows the percentages of pairings correctly performed in each session of teaching and testing.

In Group 1, with the exception of the relations between the printed numeral and operations of addition (AC/AC) to all participants and relations between numeral printed and set of points $(\mathrm{AB} / \mathrm{BA})$ for the $\mathrm{P} 1$ and $\mathrm{P} 3$, all participants had percentages above $80 \%$ in all sessions of teaching. Except for the teaching of relations $\mathrm{AB} / \mathrm{AB}$ and $\mathrm{AC} / \mathrm{AC}$ for the $\mathrm{P} 1$, the number of sessions required so that each participant reached the criterion of correct answers was less than two. As for relations tested, only for the P1 the relations between all the sets of points and operations of addition $(\mathrm{BC} / \mathrm{CB})$ and between the printed numeral and value printed $(\mathrm{AD} / \mathrm{DA})$ there were percentages of hits less than $80 \%$. For this participant in the test of relations between sets and operations of addition (BC/CC) three sessions were required so that it reaches $80 \%$ of 
GRUPO 1
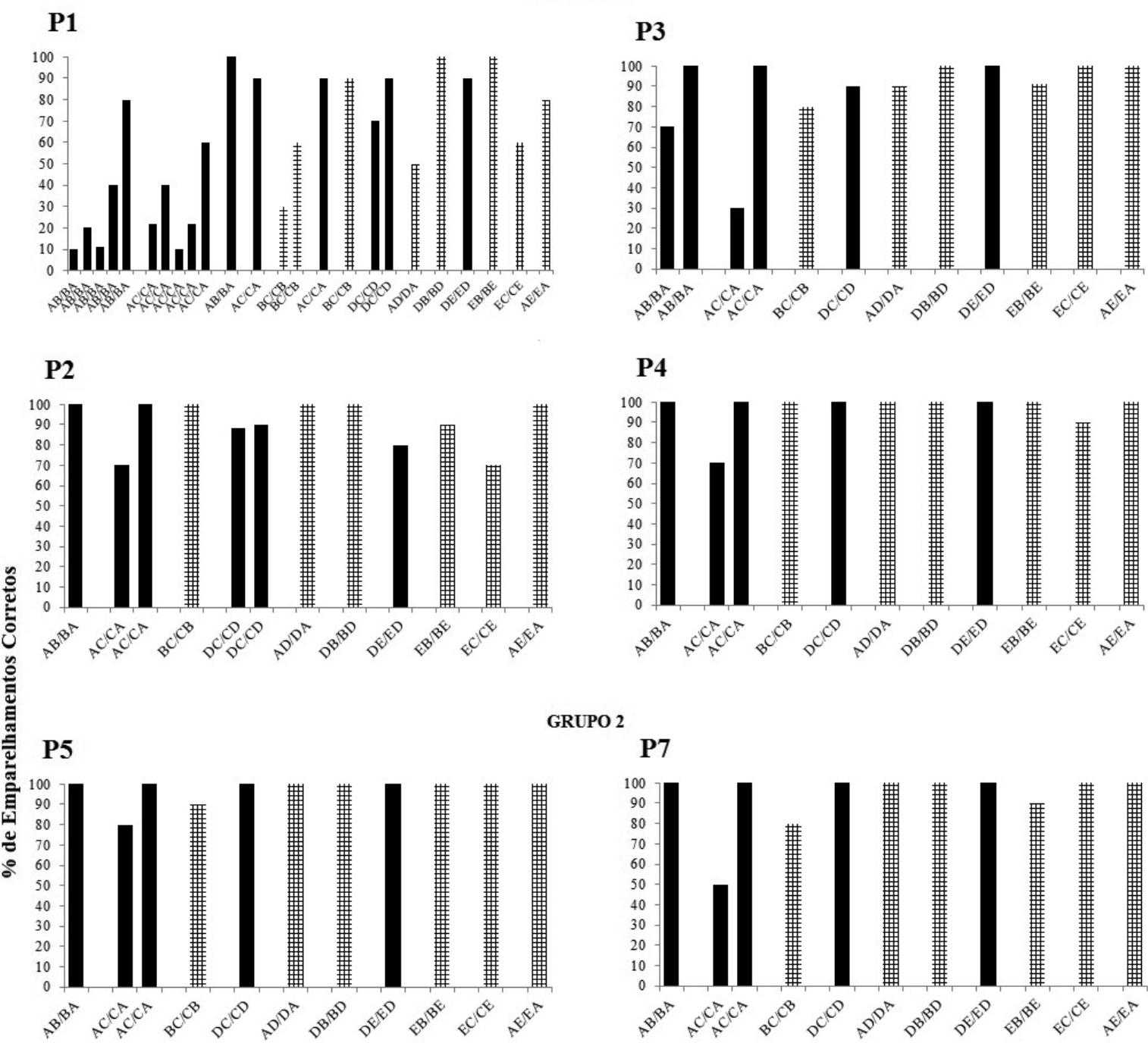

GRUPO 2
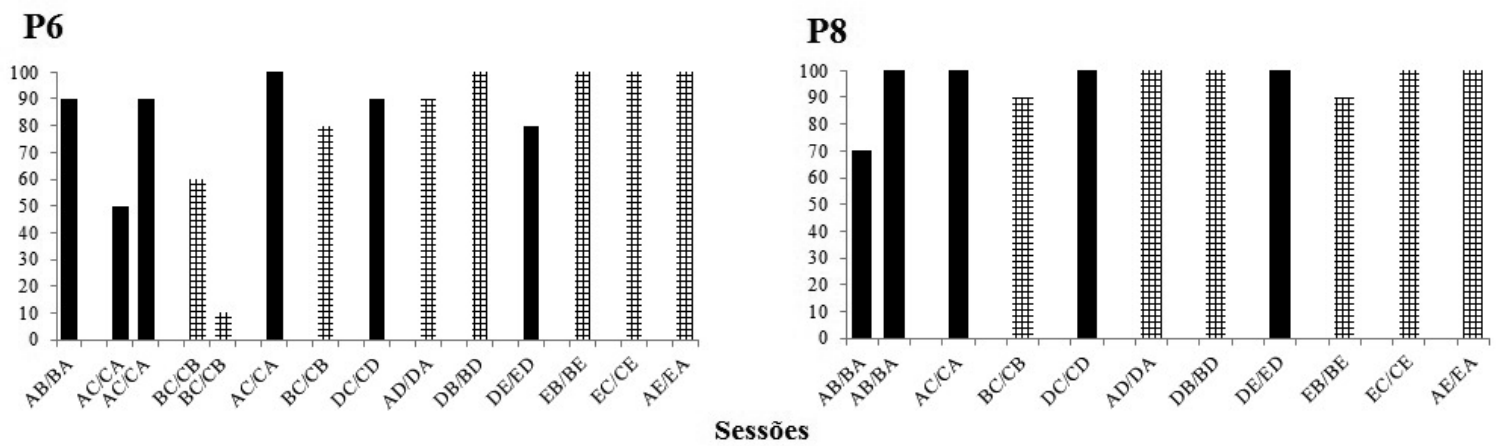

Figura 3. Percentages of correct pairings throughout the sessions. Each black column represents a session of teaching and each checked column represents a test session.

pairings compatible with the pre-determined by the researcher. In the first session, the participant paired correctly $30 \%$ of the parts, while the second paired $60 \%$. The teaching of foreign relations $\mathrm{AC} / \mathrm{CA}$ was resumed followed by new test session in which showed $90 \%$ of correct pairings of parts, which allowed its progression in the study.

In Group 2, only the P6 and P7 presented performances below $80 \%$ in the first sessions of teaching relations between numeral printed and for addition operations (AC/CA). The P8 did 
not reach the criterion in the first session of the teaching of relations between numeral printed and set of points $(\mathrm{AB} / \mathrm{BA})$. Although the $\mathrm{P} 5$ has achieved the criterion for $\mathrm{AC} / \mathrm{CA}$ in the first session $(80 \%)$, it was decided to repeat this session of teaching since the correct pairing of some parts could have occurred by chance, in agreement with the observation of the researchers. The repetition of this session had the objective of ensuring that the teaching of relations had been performed. In this second session the participant presented $100 \%$ of correct pairings.

In the relations tested, with the exception of the relations between all the points and operations of addition $(\mathrm{BC} / \mathrm{CB})$ for the $\mathrm{P} 6$, all participants had $80 \%$ of pairings that are compatible with the expected by the researcher in all sessions. In the first session of this test the participant paired correctly $60 \%$ of the parts, while in the second attempt just $10 \%$ of the moves were paired correctly. It was decided, then, to return to the teaching of $\mathrm{AC} / \mathrm{CA}$ relations. For these relations the P6, showed $100 \%$ of correct pairings. Then there was the third attempt to test the relation $\mathrm{BC} / \mathrm{CB}$, in which the participant reached $80 \%$ of hits in the pairing of the parts.

As for the number of attempts with each Domino, only P8 had a larger number of attempts in teaching regarding $\mathrm{AC} / \mathrm{AC}$. Because this is a domino, the pairing of parts could occur on both sides, fact which justifies the small number of attempts of pairings for some relations [for example, value printed and operations of addition (DC) for the P1, P2, P7 and P8, the printed numeral and operations of addition (AC) for the P2, P7 and P8 value printed and figures of bills and coin (DE) for the P2, P3, P5, P6 and P7].

Figure 4 shows the percentages of correct answers of the participants in the tasks of appointment of numeral printed, assemblies, value printed, figures of bills and coin, cash handling, operations of addition with two installments and operations of addition with three or more installments in the Pre-test, the Surveys(SONDAS) at post-test.

All participants in Group 1 had a 100\% success in the tasks of appointment of numeral printed in the pre-test. In the task of appointment of sets, P 1 showed $20 \%$ of hits, while the other participants named correctly all stimuli of this class. Only P2 named correctly the value printed on the cards in all presentations at pre-test. However, your performance in this task was variable throughout the sessions. However still in the Pre-test session, the task of appointment of bills and coin, only the $\mathrm{P} 2$ and $\mathrm{P} 4$ showed a $100 \%$ of success. The percentages of hit in an attempt of the task of money handling were below $50 \%$ for all participants. Finally, none of the participants performed the operations of addition with two or three areas before the intervention began.

With the beginning of the intervention (Figure 4) there was an increase in percentages of accuracy in the tasks of appointment of sets, after the teaching of relations with this class of stimuli, for the $\mathrm{P} 1$; in the task of appointment of bills and coin to the $\mathrm{P} 1$ and $\mathrm{P} 3$ and in the task of appointment of values for the P1, P3 and P4. As the operations of addition, we observed an increase in the percentages of correct answers to all participants in the operations of addition with two portions (from $0 \%$ to $95 \%$ for $\mathrm{P} 1$ and $0 \%$ to $100 \%$ for $\mathrm{P} 2, \mathrm{P} 3$ and $\mathrm{P} 4$ at post-test), as well as in the operations of addition with more than two portions (from $0 \%$ to $17 \%$ for the $\mathrm{P} 1$; from $0 \%$ to $50 \%$ for the $\mathrm{P} 2$; from $0 \%$ to $67 \%$ for the $\mathrm{P} 3$ and $0 \%$ to $83 \%$ for the P4). In the task of handling of money, we observed an increase in the percentages of correct responses for the P3 (25\% to $42 \%)$ and the P4 (42\% to $100 \%)$. It should be emphasized that for the P4, at the survey 1 , before the intervention began, there was an increase in the percentages of correct responses in the task of money handling and that for the P3 this increase was not significant in this same task.

For the Group 2, it is observed that all participants named correctly the sets and with the exception of P8, which obtained $60 \%$ of correct answers, all the other named correctly the numerals. In the tasks of appointment of value printed all participants had lower performance at $40 \%$ of hits. In the task of naming figures of bills and coin, only the $\mathrm{P} 7$ showed $100 \%$ of accuracy, while the other participants performed less than $70 \%$ of the attempts. None of the participants 


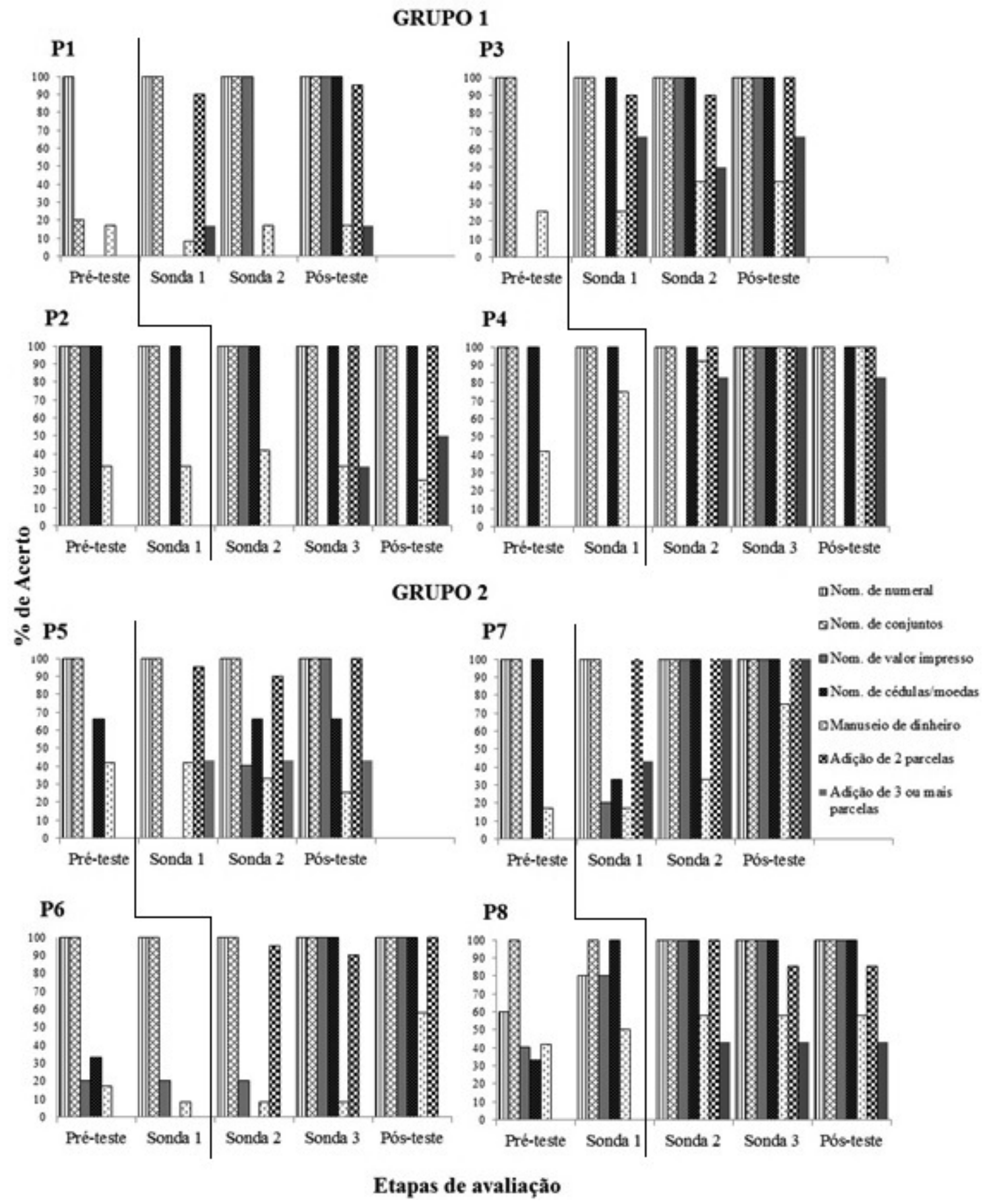

Figure 4. Percentages of correct answers of the participants in the tasks of appointment of numeral printed, assemblies, value printed, figures of bills and coin, cash handling, operations of addition with two installments and operations of addition with three or more installments in the Pre-test, the Surveys(SONDAS) at post-test. The line indicates the start of the intervention for each participant.

solved correctly the operations of addition and the percentages of correct answers in money handling were lower than $40 \%$.

From the beginning of the intervention it was observed an increase in the percentages of correct responses in the tasks of resolution of operations of addition of two portions for all participants in Group 2 (from $0 \%$ in Pre-test to $100 \%$ at post-test for the P5, P6 and P7 and $0 \%$ pre-test to $85 \%$ at post-test for the P8). There was also an increase in the percentages of correct answers in the case of P5, P7 and P8 in addition operations that were not worked by games, i.e., operations with more than two portions, for 
example, $2+1+1$ (from $0 \%$ in Pre-test to $43 \%$ accuracy in Post-test for the P5 and P8, and from $0 \%$ to $100 \%$ for the $\mathrm{P} 7)$. In relation to the task of handling money, there was an increase in the percentages of correct answers only for the P6 and P7 (17\% in Pre-test pair for 58\% and 75\% in the Post-test for P6 and P7, respectively). Regarding the appointment of values printed, P5, P6 and P7 showed an increase in the percentages of correct answers after the beginning of the intervention.

\section{Discussion}

With this study, it was expected to investigate the effect of the use of games in the steps of Pre-test and surveys on the performance of pre-school students in mathematical and monetary skills. The results of both groups corroborate those of Godoy et al. (2015), regarding the possibility of teaching of conditional relations by means of adapted dominoes. However, the duration of the matches with the dominoes was lower for most participants in this study. A variable that may have contributed to these results was the change in the initial instruction, since in the present study, before the beginning of each session of teaching it was presented the correct model of pairing of two parts with values of 1 and 2 of the domino.

The addition of this instruction may have facilitated the understanding of the task, reducing the time needed for the completion of the sessions. The fact of the participants of the Groups 1 and 2 make better initial repertoire, especially in the tasks of appointment of numerals and sets of the Pre-test, in which seven out of the eight participants had $100 \%$ success in attempts, in relation to the participants in the study by Godoy et al. (2015) who presented performance below $70 \%$ in these same tasks, may have also contributed to the difference in the results found.

Another variable that may have contributed to the better results in comparison to those found by Godoy et al. (2015) was the addition of an instruction provided to participants P3, P4, P7 and $\mathrm{P} 8$ before the tasks of handling money (activity) For those participants it was provided the following statement before the completion of the tasks "- You can make the calculations, as you do in the domino". After this statement, it was observed an increase in the percentage of correct responses to $\mathrm{P} 7$ (17\% in the pre-test for $75 \%$ post-test) and P4 (42\% to $100 \%)$. Even so, it is not possible to say that this statement is the variable that contributed to the change in the classes of responses related to handling of money, since not all participants who received the instruction presented superior performance to that observed prior to instruction.

It was also found that the majority of the participants (P1, P2, P6, P7 and P8) held more attempts of pairings from class $\mathrm{C}$ to class $\mathrm{B}$ (operations of addition and sets) in the first domino (Domino test 3 ). The complexity of the task could explain this preference, since that pairing the result with the addition operation can be an easier task than pairing the addition operation with its result. To make a pairing CB it was necessary that the participant solved the addition operation prepared in the last part of the result placed on the table, for example " $2+1=$ " to choose the result in one of the faces of their parts ( 3 points), while to make a pairing $\mathrm{BC}$ the participant had by model the result of the operation, in the form of set of points, for example, the 3 points arranged on the table and should find the addition operation correct in their parts (some options would be, for example: $2+1=; 1+2=; 3+0=$ ). Thus, it was possible that the child had to solve more than one operation, whose result could be different than the one expected (ex. $1+1=; 4+0=$, etc.) until he found a piece that could be paired with the model part that was on the table.

It was observed that the majority of the participants (except for the P8) presented difficulty performing pairings of classes $\mathrm{BC}$ and $\mathrm{CA}$, being necessary to repeat once the teaching session of this relation for the $\mathrm{P} 2, \mathrm{P} 3, \mathrm{P} 4, \mathrm{P} 5, \mathrm{P} 6$ and $\mathrm{P} 7$ and five times for the P1. These results corroborate the findings by Godoy et al. (2015), who emphasized greater difficulty of their participants in line with the dominoes with the class of stimuli for addition operations. According to the authors, this task is more complex as it requires several skills such as identifying numbers, rec- 
ognition of the + sign, resolution of the operation among others.

Despite of the need for repetition of teaching sessions with operations of addition, the results found in assessments of skills seem promising. At the beginning of the study, no participant was able to solve the operations of addition, however, it was found at Post-test high percentages of correct answers in the resolution of operations of addition with two portions for all participants (95\% for the P1, 85\% for the P8 and $100 \%$ for the other participants). It is also pointed out that the form of presentation of the operations of addition (one below the other so that the participant could write or speak the result in Group 1 and in activity to connect the operation with outcome in Group 2) seems not to have interfered with the results, since all participants had percentages of accuracy above $80 \%$ in the resolution of operations of addition of two portions at the end of the intervention.

The tests of conditional relations were conducted by means of the dominoes 3, 5, 6, 8, 9 and 10. In spite of encouraging the involvement in the games, these tests may have offered a problem of experimental control, since the researcher was playing with the participant, and even if he was not able to provide a feedback on the moves, he could provide a model of moves correct for the participants to perform pairings during his turn to play. For example, in the domino 3 there are two parts to the stimuli " $1+1=$ " and it was possible that each player stayed with one of them during the drawing of parts and that the researcher performed the move with this part before the participant, thus being able to provide a model of correct pairing.

The results indicated that the participants learned the relations taught by means of games of dominoes, as well as the emergence of the majority of the relations tested (except the relations $\mathrm{AD} / \mathrm{DA}$ and $\mathrm{CE} / \mathrm{EC}$ for the $\mathrm{P} 1$ and the relation/EC for the $\mathrm{P} 2$ ). These results corroborate the data from other studies based on network models of relations and equivalence of stimuli for the teaching of concepts and mathematical and monetary skills (Haydu et al., 2006; Jackson et al., 1989; Rossit \& Goyos, 2009). In gen- eral, the results of both groups presented in this study have confirmed the feasibility of games of dominoes adapted for the teaching of some mathematical and monetary skills, such as the resolution of operations of addition, the appointment of printed values and figures of bills and coins. Several studies have been conducted using educational games as tools (Souza \& Hübner, 2010; Xander et al., 2016) and suggest the efficiency while teaching strategies that facilitate learning through natural consequences (Panosso et al., 2015).

Some studies that used games for teaching, but made use of traditional activities of pen and paper (cards, for example) or softwares for the tests suggest that the instruments used for evaluation of skills were not, in some cases, efficient to evaluate what they wanted (Xander et al., 2016). In the work of Godoy et al. (2015) dominoes were used as tools of aid to education, however, the tests of appointment were performed with the use of cards. In the present study, for Group 1, the skills assessment was similar to that obtained with the participants in the study by Godoy et al. (2015), while for the group 2, the evaluation in the tasks of appointment was conducted through games. When comparing the results obtained in tests of appointment in the two studies, there is little evidence that the games used as assessment tools can provide results with less variability between sessions of evaluation of a participant, since the variability of performance observed in the answer of the participants in Group 1 was higher than that of group 2 .

The variability was observed in situations in which a class of stimuli was correctly named ( $100 \%$ of correct answers) in a survey, but not in all the subsequent evaluations. In group 1 it was observed such variability for some participants. The P2, for example, has appointed correctly the class of stimuli "printed value" on the pretest and the survey 2, but did not appoint these stimuli at the subsequent tests. This was also observed for P4, that appointed him correctly the class "Value printed" on the survey 3 , but has not retained the same performance at the Posttest. The data from Group 2 did not indicate such variability, since that the response of naming a 
class of stimuli correctly $(100 \%)$ on one of the steps of evaluation was always kept in the subsequent evaluations. These data, however, should be analyzed with caution, since that most of the participants already had initially the ability to appoint some of the classes taught by games of dominoes and tested by the presentation of cards or by means of games "Tapa Certo".

When comparing the time for performing the tests between groups, it is observed that the evaluations of Group 2 lasted longer than those of group1. It was necessary two sessions of approximately 20 minutes to complete the tests of appointment for Group 2 while for group 1 it was necessary in only one session of no more than 5 minutes. Even though the time for performing the tests for appointment to the Group 2 was greater, the fact that the children asked to play with the games that comprised the surveys provides evidence that the time did not affect their interests for the tasks that were presented. It is possible that the use of the games "Tapa Certo" between sessions with the games of dominoes may have contributed, including with the sessions of teaching as at the Survey sessions the participants from Study 2 could play with other games, thus avoiding the constant repetition of the sessions with the domino.

Future studies could choose more carefully the participants so that the initial repertoire was similar. This would allow a more accurate assessment of the effects of the games as teaching tools and test on mathematical and monetary skills. It is suggested the extension of the base line to check stability in the participants' responding prior to the start of the intervention and change in the structure of the tests of conditional relations to ensure that the researcher does not provide a model of correct answers. It is also suggested the increasing of the number of stimuli in classes, considering the ability of subitizing sets with few elements.

Studies that have evaluated the formation of equivalence classes among different forms of presentation of addition operation (Haydu et al., 2006; Haydu, Lorencete, \& Eccheli, 2015), and operations of addition and subtraction (Henklain $\&$ Carmo, 2013) showed good results in resolv- ing problems and could subsidize future studies in which other forms of presentation of problems were included in the dominoes. Finally, it would be interesting to evaluate the arithmetical pre-requisites and the formation of concept of number in order to better evaluate variables that could produce inconsistent performances among the participants.

\section{References}

Cavaletti, R. L., \& Carmos, J. S. (2012). Ensino de habilidades no uso de dinheiro a idoso com perda de memória por meio de relações condicionais e equivalência. Interação em Psicologia, 16(2), 185-197. doi:10.5380/psi.v16i2.25312

Escobal, G., Rossit, R. A. S., \& Goyos, C. (2010). Aquisição de conceito de número por pessoas com deficiência intelectual. Psicologia em Estudo, 15(3), 467-475. Retrieved from http://www. scielo.br/pdf/pe/v15n3/v15n3a04.pdf

Fields, L., Travis, R., Roy, D., Yadlovker, E., Aguiar-Rocha, L. D., \& Sturmey, P. (2009). Equivalence class formation: A method for teaching statistical interactions. Journal of Applied Behavior Analysis, 42(3), 575-593. doi:10.1901/jaba.2009.42-575

Godoy, M. C. J., Alves, H. W., Xander, P., Carmo, J. S., \& Souza, S. R. (2015) Ensino de equivalência monetária por meio de um jogo de dominó adaptado. Acta Comportamentalia, 23(2). Retrieved from http://www.redalyc.org/articulo. oa? $\mathrm{id}=274538523003$

Hammond, J. L., Hirt, M., \& Hall, S. S. (2012). Effects of computerized match-to-sample training on emergent fraction-decimal relations in individuals with fragile X syndrome. Research in Developmental Disabilities, 33(1), 1-11. doi:10.1016/j.ridd.2011.08.021

Haydu, V. B., Costa, L. P., \& Pullin, E. M. M. P. (2006). Resolução de problemas aritméticos: Efeito de relações de equivalência entre três diferentes formas de apresentação dos problemas. Psicologia: Reflexão e Crítica, 19(1), 44-52. doi:10.1590/S0102-79722006000100007

Haydu, V. B., Lorencete, C. M., \& Eccheli, S. D. (2015). Equivalência de estímulos entre três formas de apresentação de problemas aritméticos: Um estudo com adultos e idosos. Temas em Psicologia, 23(1), 49-67. doi:10.9788/TP2015.1-04 
Henklain, M. H. O., \& Carmo, J. S. (2013). Equivalência de estímulos e redução de dificuldades na solução de problemas de adição e subtração. Psicologia: Teoria e Pesquisa, 29(3), 341-350. doi:10.1590/S0102-37722013000300012

Magalhães, P. G. S., \& Assis, G. J. A. (2011). Equivalência monetária em surdos. Temas em Psicologia, 2, 443-458. Retrieved from http:// pepsic.bvsalud.org/scielo.php?pid=S1413389X2011000200008\&script=sci_arttext

Magalhães, P. G. S., Rossit, R. A. S., \& Assis, G. J. A. (2013). Ensino de relações condicionais entre valores monetários por meio da exclusão para crianças surdas. Acta Comportamentalia, 21, 305-324. Retrieved from http://www.redalyc. org/articulo.oa?id=274528346003

Monteiro, G., \& Medeiros, J. G. (2002). A contagem oral como pré-requisito para a aquisição do conceito de número com crianças pré-escolares. Estudos em Psicologia (Natal), 7(1), 73-90. doi:10.1590/S1413-294X2002000100009

Panosso, M. G., Souza, S. R., \& Haydu, V. B. (2015). Características atribuídas a jogos educativos: Uma interpretação Analítico-Comportamental. Revista Brasileira de Psicologia Escolar e Educacional, 19(2), 233-241. doi:10.1590/2175$3539 / 2015 / 0192821$

Prado, P. S. T., \& de Rose, J. C. (1999). Conceito de número: Uma contribuição da análise comportamental da cognição. Psicologia: Teoria e Pesquisa, 15(3), 227-235. doi:10.1590/S010237721999000300006

Ribeiro, M. P. L., Assis, G. J. A., \& Enumo, S. R. F. (2007). Comportamento matemático: Relações ordinais e inferência transitiva em pré-escolares. Psicologia: Teoria e Pesquisa, 23(1), 25-32. doi:10.1590/S0102-37722007000100004

Rossit, R. A. S., \& Goyos, C. (2009). Deficiência intelectual e aquisição matemática: Currículo como rede de relações condicionais como rede de relações condicionais. Revista Semestral da Associação Brasileira de Psicologia Escolar e Educacional, 13(2), 213-225. doi:10.1590/ S1413-85572009000200003

Rossit, R. A. S., Ramos, L. Z., \& Lopes, C. F. (2010). Desempenho de idosos em tarefas matemáticas de discriminação condicional auditiva e visual. Revista Brasileira de Análise do Comportamento, 6(2), 149-166. Retrieved from http://www. periodicos.ufpa.br/index.php/rebac/article/ viewFile/1116/1678
Sidman, M. (1971). Reading and auditory-visual equivalences. Journal of Speech and Hearing Research, 14, 5-13. doi:10.1044/jshr.1401.05

Sidman, M., Kirk, B., \& Willson-Morris, M. (1985). Six-member stimulus classes generated by conditional-discrimination procedures. Journal of the Experimental Analysis of Behavior, 43, 2142. doi:10.1901/jeab.1985.43-21

Sidman, M., \& Tailby, W. (1982). Conditional discrimination vs. matching to sample: An expansion of the testing paradigm. Journal of the Experimental Analysis of Behavior, 37(1), 5-22. doi:10.1901/jeab.1982.37-5

Skinner, B. F. (1972). Tecnologia do ensino. São Paulo, SP: Herder. (Original work published 1968)

Souza, S. R., \& Hübner, M. M. C. (2010). Efeitos de um jogo de tabuleiro educativo na aquisição de leitura e escrita. Acta Comportamentalia, 18, 215-242. Retrieved from http:// pepsic.bvsalud.org/scielo.php?pid=S0188$81452010000200003 \&$ script $=$ sci

Stoddard, L. T., Brown, J., Hurlbert, B., Manoli, C., \& McIlvane, W. J. (1989). Teaching money skills through stimulus class formation, exclusion, and component matching methods: Three case studies. Research in Developmental Disabilities, 10(4), 413-439. doi:10.1016/08914222(89)90041-3

Xander, P., Haydu, V. B., \& de Souza, S. R. (2016). "DimDim: Negociando e Brincando" no ensino de habilidades monetárias a pré-escolares. $C E S$ Psicología, 9(1), 65-88.
Recebido: 02/02/2016

$1^{a}$ revisão: 26/05/2016

$2^{a}$ revisão: 08/06/2016 Aceite final: 16/06/2016 